\author{
Jolanta Chluska \\ Czestochowa University of Technology \\ e-mail: Jolanta.chluska@wz.pcz.pl
}

\author{
Aleksandra Szewieczek \\ University of Economics in Katowice \\ e-mail: Aleksandra.szewieczek@ue.katowice.pl
}

\title{
THE USE OF COST INFORMATION IN THE REPORTS AND FINANCIAL ANALYZES OF HOSPITAL
}

\section{WYKORZYSTANIE INFORMACJI KOSZTOWYCH W RAPORTACH I ANALIZACH FINANSOWYCH SZPITALA}

DOI: $10.15611 /$ pn.2018.524.02

JEL Classification: I19, M41.

Summary: Evaluation of hospital standing is one of the tasks of the funding bodies of hospitals. The evaluation is made based on the indices of measurements specified in the Ordinance of the Minister of Health. These indices relate to various areas of hospital activities, including their financial results. There are no indices based directly on costs. The aim of the study is to identify the role of costs as a basis for the evaluation of economic and financial status of hospital. The research hypothesis states: it is necessary to increase the role of hospital operating costs in the assessment of their economic-financial condition. The research tools included the analysis of legal acts, related literature and practical examples of hospital reports on economic and financial situation of independent public health care institutions. Final conclusions were developed using the method of deduction and synthesis.

Keywords: hospital, costs, analysis, evaluation of economic and financial standing of hospitals.

Streszczenie: Ocena kondycji szpitali jest jednym z zadań podmiotów je tworzących. Jest ona dokonywana na podstawie wskaźników pomiaru ustalonych w rozporządzeniu Ministra Zdrowia. Wskaźniki te odnoszą się do różnych obszarów działalności szpitali, w tym ich wyniku finansowego. Brak jest wskaźników opartych na kosztach zakładów. Celem opracowania jest identyfikacja roli kosztów jako podstawy oceny kondycji ekonomiczno-finansowej szpitala. Hipoteza badawcza brzmi: niezbędne jest zwiększanie roli kosztów działalności szpitala w ocenie jego kondycji ekonomiczno-finansowej. Dla realizacji przyjętego celu i weryfikacji postawionej hipotezy, jako narzędzia badawcze przyjęto analizę aktów prawnych, literatury przedmiotu oraz przykładów praktycznych raportów szpitali o sytuacji ekonomiczno-finansowej spzoz, wnioski końcowe zostały opracowane z wykorzystaniem metody dedukcji i syntezy.

Słowa kluczowe: szpital, koszty, analiza, ocena kondycji ekonomiczno-finansowej szpitali. 


\section{Introduction}

Every entity that manages property and consequently generates streams of costs and revenues acts for the achievement of its goals. These goals mostly adopt financial form, although this is not the regular pattern. Large group of entities, related to varied degree with the sector of public finance, operates not to achieve financial surplus but in order to achieve other goals: mainly with social character. However, this does not limit the significance of finance management in these entities. Furthermore, these problems are often more complex.

One example are entities of health sector, including hospitals. The entities are often extended in terms of the structure and complexity of the activities taken by the entities, financed mostly from public funds. The idea of their activity is to protect people's health and life. Nevertheless, it is required that they cover the costs on their own from revenues [Chluska 2017]. Business practice shows, however, that this is not easy. A specific challenge is also the fact that management of the area of revenues is not flexible whereas obtaining revenues is substantially limited. Observation of the market of hospital sector in Poland shows that this market is very difficult, with most public hospitals failing to reach positive financial results [Puls Medycyny 2016; Puls Medycyny 2017]. Commercial hospitals, if they rest their operation of public financing, are also challenged with financial difficulties.

The above shows unequivocally that a particularly important problem in finance management in health care are financial streams of incomes and costs, especially those disclosed, evaluation and analysis of costs and management of these costs. This topic is also very complex due to the examination of the area of varied services, necessity of ensuring adequate resources of varied character, occurrence of specific phenomena that affect specific costs of functioning of this sector.

The aim of the study is to identify the role of costs as a basis for evaluation of the economic and financial condition of hospital.

The research hypothesis states: it is necessary to increase the role of hospital operating costs in the assessment of their economic-financial condition.

In order to achieve the adopted study aim and verify the hypothesis, the research uses different tools.

The presentation of the specificity of the financial perspective of hospital operations, the rigidity of sources of income and specific attributes of the costs of medical activities, as well as their location in financial analyzes was carried out using the method of meta-analysis of the legal acts, related literature, observation and deduction.

Audit of financial statements of hospitals in the direction of positioning information on costs was made taking into account the methods of the systematic review and critical analysis and reasoning. In the further stage of the research, the method of observation and analysis of the independent public health care institutions 
(SPZOZ) was used. Final conclusions were reached using the method of deduction and synthesis.

\section{Hospital as an object of cost accounting}

In light of the act on medical activity [Act of 15 April 2011, Art. 2], hospital is a medical institution which provides hospital services. Hospital services are understood to mean stationary and all-day medical services (provided within 24 hours), which are comprehensive and can be provided in various forms. Similar to most of other business entities, hospital is also a kind of enterprise that attempts to achieve the goals based on a set of organized material and non-material components.

The aim of this activity is to maintain, save, recover and improve human health status. These activities lead naturally to the consumption of resources and generation of other costs, e.g. in the form of readiness for providing services.

It should be noted that, on the other hand, hospitals are similar to other enterprises as they independently control (with some limitations) the property components in order to perform assigned tasks and achieve goals and cover the costs for the generated revenues. The dichotomic nature of hospital functioning is reflected in the presented goals, among which the dominant space is filled by the goals with social character. Therefore, the highest challenge is to relate these goals to the necessity of balancing costs and revenues of hospital and striving for generating of financial surplus.

The next differentiation is observed in ensuring the constant readiness for providing health care services, whether or not the demand occures. Another one concerns the complexity and variation of the services provided, resulting from their personalization and specific determinants of performing the services [Walshe, Smith 2011, p. 27].

Therefore, it is possible to find that hospital managers are facing specific challenges and, although this should not obscure social goals, financial aspects are also important.

While focusing on the area of financial streams, one should not neglect the fact that the main area of effect are costs. This is connected with relatively poor flexibility of prices and hospital revenues. The prevailing part of revenues is acquired from public funds, additionally limited by the frameworks of contracts, which substantially limits the opportunities for their development. In 2012-2014, the level of financing in hospitals by the National Health Fund (NFZ) reached $96.9 \%$ of revenues, whereas in hospitals transformed from public hospitals, this number was $94.2 \%$ [Magellan 2014]. The structure of financing is substantially rigid, with additional difficulty in recent years being a new evaluation of medical procedures, which significantly contributed to the decline in revenues of hospitals in this part of medical services that had allowed for subsidizing underestimation of other medical procedures [www. polskieradio.pl; www.rmf24.pl]. It should be noted that in the ranking of the list 
of the biggest hospitals in Poland in 2014 [Puls Medycyny 2016], the total of the results of the first twenty biggest entities is the negative value. This situation did not change significantly another year. The total of financial results of hospitals included in another ranking (500 entities) is also negative. Although more than half of the entities made profits, the positive aspect of this situation is disturbed by the fact that in many cases the positive results come from the settlement of subsidies obtained from the founding body [Puls Medycyny 2017], which is reflected by its partially apparent character.

Consequently, this characteristic strengthens the importance of cost management. The literature has emphasized this financial area as especially important [Giancotti et al. 2017; Chluska 2011; Macario et al. 1995].

The indicated determinants and processes that impact on the adoption of specific solutions in organization of hospital activities [Szewieczek 2017] lead consequently to the development of specific patterns of costs of hospital operation. Among cost attributes in hospitals are:

- presence of "empty" costs connected with readiness for providing health services,

- high costs of maintaining technical and technological facilities and resources and the related high level of fixed costs,

- dominant personal costs, including implicit costs in the position of outsourced services,

- variable structure of costs of operational activities depending on the adopted business model,

- maladjustment of the structure of the level of financial results in terms of commensurability of the depreciation costs concerning their revenues from external sources of finance settled over time (deferred income).

The literature on the problems of cost management highlights the particular role of cost account in health entities and its reporting effects. As identification, documentation, evaluation, recording, settlement and reporting system for the costs of operation in various areas, cost account in hospital is much varied.

On the one hand, this is connected with frequent but not always consistent use of the provision of already obsolete regulation on specific principles of cost accounting [Rozporządzenie Ministra Zdrowia i Opieki Społecznej z dnia 22 grudnia 1998]. On the other hand, new regulations were implemented in this area, although the obligation of using them was deferred to 2020 [Rozporządzenie Ministra Zdrowia z dnia 8 lipca 2015]. Furthermore, the biggest challenge for the system in the health service is not only the substantial variety of the costs but also the necessity to ensure cooperation of two separate areas of activity: medical activity and non-medical activity (supporting and administrative).

The analysis of the costs of hospital with consideration for the criterion of their usefulness for the examination of the achievement of the goals, reporting specific information reveals their classification into: 
- main operating costs, other operating costs, and financial costs, reflected in the structure of the cost reporting for reporting purposes,

- costs of core activities, auxiliary (supporting) activities, management,

- costs of depreciation, material and energy consumption, salaries with overheads, outsourced services, taxes and payments, other costs,

- costs of performance of health services, empty costs (ensuring readiness for providing health services and other costs).

Recently, the particular interest [Raulinajtys-Grzybek 2016; Kotapski 2016; Kujawska 2014] has been focused on empty costs in hospitals and striving for the separation of the items related to maintaining readiness for providing health services and unneccesary costs. Although not directly leading to the effects in the form of health services, the costs of readiness ensure the efficient services in emergency situations.

\section{Revenues and costs of hospital in external reporting}

The reporting fullfiled by hospital, especially public ones, is a very broad issue. It includes in particular:

- financial reporting, regulated by balance sheet law regulations,

- statistical reporting,

- reporting for the supervisory needs (for the founding body),

- for the purposes of the National Health Fund (NHF - public payer),

- other, including the Agency for Health Technology Assessment and Tariff stem (AOTM), budget reporting (mainly in budgetary entities and partly in public hospitals).

Apart from the above listed parties, the recipients of the reports are mainly state authorities (regulatory, statistic, fiscal etc.), society and local environment and also capital givers.

When making a systematic review of existing patterns of obligatory financial, statistical and budget reports made by hospitals it should be pointed that no one focused on the particular examination of the level and content of hospital costs.

The costs are usually presented in synthetic terms, in the classic division by type and according to the calculation system (the cost of services sold, overhead costs). Some reports present additional cost classifications, such as costs of drugs, medical consultations, medical transport (reports for NHF). However, they are usually selective in that they relate to separate medical cases and do not present in detail all the costs involved. The purpose of their presentation is to obtain additional, occasional financing. Reports prepared for AOTM are also selective, occasional and prepared for top-down price formation, not for management of the entity. What is more, they concern only selected areas of activity and are subject to significant modifications depending on current needs. 
Also recent changes in law area do not allow for expecting changes in this pattern. The ordinance as of 12 April 2017 that defines basic economic and financial indices for evaluation of independent public health care institution introduced, in order to ensure uniform point scores, the indices concerning:

- profitability,

- liquidity,

- performance (efficiency),

- debt.

Among 11 indices for evaluation, none concerns the value of costs, two are based on values of revenues on sales (efficiency index), and three are based on value added of net result (profitability indices). The description of the profitability indices leads to the presumption that they are also computed for the negative financial result. This approach has been observed in the literature [Cygańska 2015]. However, it does not provide any important indications for the interpretation of these results. It should be additionally taken into account that the profitability can be understood as either earning capacity or unprofitability [Bednarski 2007, p. 96].

The costs in such analyses are not used directly but only indirectly, through the development of the level of financial result used for the computation of profitability ratios. If the cost-based indexes or their relations are entirely neglected, this reflects the lack of interest in this area or the consequence of problems with proper interpretation of their value and opportunities for making comparisons.

A comparison of such solutions with indicated problems of revenues and costs in hospitals shows that the attention of decision-makers is not focused on right areas. The reported indices are significant, but these are costs which require much more attention. This leads to the conclusion that actual responsibility for financial results is left solely on the micro level.

\section{Hospital costs in the analyses of profitability}

Costs are a very complex category. In addition to a variety of classifications of costs, there are many other factors, among others:

- endogenous factors (size of a hospital, scope of activities, location, organizational structure, condition of infrastructure, quality of management and control),

- exogenous factors (legal regulations that impact on cost items, competition, conditions of the contracts concluded with payers for health services, local social and political effects).

Costs represent an important item used in the evaluation of hospital profitability. By comparing them with revenues, they allow for the determination of the result on a specific part of activities.

The analysis of profitability occurs in general according to the following pattern: 


$$
\text { Profitability ratio }=\frac{\text { financial result }}{\text { base of reference }} \times 100 \text {. }
$$

The financial result can be:

- profit on sales,

- profit on operating activities,

- gross profit,

- net profit.

The reference can be profited by:

- assets,

- revenues,

- capital.

An important component that impacts on financial result is value of costs incurred. If revenues exceed costs, the result is profit. If the costs are higher than revenues, the hospital bears a loss. Profitability indices are a correct indicator of hospital accomplishments if the financial results and the base of reference are values on which the hospital can have an effect. The analysis of the base of reference for profitability indices raises some doubts about the influence of hospitals on the level of revenues. Revenues often settle on the level defined by the payer (National Health Fund) and, with a low level of financing of the entire sector, negotiations in this area are impossible. One of the methods to balance costs and revenues is to reduce costs. Founding bodies should be interested in the level of costs incurred by hospitals, at least in order to evaluate if the quality or level of services is not at risk of deterioration.

As mentioned above, a legal tool for the analysis of financial standing of hospitals is the Ordinance of the Minister of Health on economic and financial indices (...) [Rozporządzenie Ministra Zdrowia z dnia 12 kwietnia 2017]. As it can be found in the ordinance, this evaluation is based on three profitability indices:

a) net profitability (\%), calculated as:

\section{Net profit $\times 100 \%$}

Net revenues on sales of products + net revenues on sales of goods and materials + other operating revenues + financial revenues

b) net profitability on operating activities (\%), calculated as:

Profit on operating activities $\times 100 \%$

Net revenues on sales of products + net revenues on sales of goods and materials + other operating revenues

c) return on assets (\%), calculated as:

$$
\frac{\text { Net profit } \times 100 \%}{\text { Average value of assets }}
$$

Individual indices were assigned points from 0 to 5 , depending on the value of the index. Costs in these indices are taken into consideration as an element of 
financial result. If one assumes that the costs lead to liabilities, the indices that take into consideration the liabilities can indirectly indicate financial standing of a hospital depending on the level of incurred costs.

The literature proposes specific measures of economic analysis based on costs used in health care, such as cost-profit analysis, cost-efficiency analysis, cost-effect analysis, cost-utility analysis. They allow for the evaluation of the effectiveness of activities and determination of the activities which effectively impact on the improvement in the patient's health status or, offering the same treatment effects, involve lower costs [Rój 2006, p. 102]. The related literature also points to the indices of the analysis of the financial area of hospital activities with consideration for costs. These indices have significant cognitive and analytical values. They include:

- unit costs of medical procedures, DRG, man-day,

- index of the level of costs of medical activities or costs of other areas,

- costs of one piece of medical advice (service),

- average cost of medicines per patient,

- average cost of human resources per patient,

- index of personal costs in costs in total,

- costs of one inpatient,

- indices of cost structure,

- ratio of direct costs to costs in total,

- ratio of overhead costs to costs in total [Kludacz 2010, pp. 235, 237].

Indices based on costs offer opportunities for comparison of both individual hospitals and from macro level. The supplementation of analyses with various cost perspectives, their structure, dynamics and parameters (both with internal and external character) that impact on their value would enrich a general image of hospitals in the system of health care. As shown by the analysis of published reports, health entities are extending the reports. This makes them more informative and explains not always positive values of individual indices.

\section{Costs in the evaluation of opportunities for the continuation of hospital activities}

Knowing the level of financing by the payer, hospitals can undertake several activities concerning planning and control of costs. Necessity of balancing revenues and costs is often achieved through budgeting. SPZOZ allows them planning and evaluation of the financial results.

For the purposes of the analysis of economic and financial standing, three reports on economic and financial situation of hospitals were chosen (Radomski Szpital Specjalistyczny im. dr. Tytusa Chałubińskiego w Radomiu, Samodzielny Publiczny Zakład Opieki Zdrowotnej Zakład Pielęgnacyjno-Opiekuńczy w Jaworznie, Samodzielny Publiczny Zakład Opieki Zdrowotnej w Sulęcinie) and compared in Table 1. 
Reports cover the previous fiscal year and forecasts for the next three years [Act of April 15, 2011, Article 53 a].

Table 1. Profitability indicators of selected hospitals for the period of 2016-2019 (\%)

\begin{tabular}{|c|c|c|c|c|}
\hline \multicolumn{5}{|c|}{ Hospital 1. (Radom) } \\
\hline \multirow{2}{*}{ Indicator } & \multirow{2}{*}{2016} & \multicolumn{3}{|c|}{ Forecasts of indicators and financial streams } \\
\hline & & 2017 & 2018 & 2019 \\
\hline Net profitability & -8.02 & -7.11 & -6.52 & -3.28 \\
\hline $\begin{array}{l}\text { Net profitability on operating } \\
\text { activities }\end{array}$ & -6.75 & -5.67 & -3.21 & -1.02 \\
\hline Return on assets & -10.18 & -9.42 & -8.01 & -6.25 \\
\hline Operating expenses (PLN thousand) & 149630 & 156974 & 157820 & 155651 \\
\hline $\begin{array}{l}\text { Net revenues of sales } \\
\text { (PLN thousand) }\end{array}$ & 131618 & 139628 & 140312 & 138522 \\
\hline \multicolumn{5}{|l|}{ Hospital 2. (Jaworzno)* } \\
\hline \multirow[t]{2}{*}{ Indicator } & \multirow{2}{*}{2016} & \multicolumn{3}{|c|}{ Forecasts of indicators } \\
\hline & & 2017 & 2018 & 2019 \\
\hline Net profitability & -4.41 & -6.93 & -5 & -4.5 \\
\hline $\begin{array}{l}\text { Net profitability on operating } \\
\text { activities }\end{array}$ & -4.51 & -6.97 & -5.05 & -4.56 \\
\hline Return on assets & -4.22 & -6.28 & -5.21 & -5.2 \\
\hline \multicolumn{5}{|l|}{ Hospital 3. (Sulęcin)* } \\
\hline \multirow[t]{2}{*}{ Indicator } & \multirow{2}{*}{2016} & \multicolumn{3}{|c|}{ Forecasts of indicators } \\
\hline & & 2017 & 2018 & 2019 \\
\hline Net profitability & 1.03 & -1.27 & -1.83 & -1.82 \\
\hline $\begin{array}{l}\text { Net profitability on operating } \\
\text { activities }\end{array}$ & 1.04 & -1.29 & -1.83 & -1.82 \\
\hline Return on assets & 0.97 & -1.24 & -1.89 & -1.89 \\
\hline
\end{tabular}

* Data related to "operating expenses" and "net revenuses of sales" are presented only for Hospital 1 due to the fact that in-depth analysis was formed for the cognitive purposes and the limited scope of the article only for that entity. Against this background it is possible to carry out parallel analyzes in Hospital 2 and Hospital 3

Source: own study based on selected hospital's data [Hosp1; Hosp2; Hosp3].

An analysis of Hospital 1 reveals a very difficult financial standing in both 2016 and in prognoses for the following three years. In light of current provisions of the act on medical activity (Art. 59), the founding body should urgently take the corrective steps to cover the specific part of net loss or to liquidate the entity. The prognoses 
of revenues and costs for consecutive years also show the lack of covering costs by revenues. This is even more complicated by the level of over-limit services, not covered from the National Health Fund in individual periods. In 2014-2016, this was 5,605 thousand zlotys. The costs were incurred for these services, but revenues will not be generated. The corrective measures for the following three years in Hospital 1 were:

- organizational restructuring,

- cost restructuring, including optimization of material and energy consumption,

- debt restructuring,

- increase in revenues on sales.

In 2014-2016, material and energy consumption was $21.92 \%, 21.91 \%$ and $22.04 \%$ of total expenses, respectively. As shown by the structure indices, the hospital failed to reduce these costs. The highest item in the cost structure was salaries and overheads, with

- salaries $49 \%, 50 \%, 48 \%$, respectively and

- salary overheads of $10 \%$ each year.

It should be expected that organizational restructuring and increased revenues improve the entity standing and savings in the areas of costs that represent $80 \%$ of costs in total.

As demonstrated in the next examples of hospitals, they are in difficult financial standing and require urgent corrective measures. Even for the hospital that generated profit, prognoses deteriorated the situation for the consecutive years. Their prognoses for the following years suggested the risk of discontinuation of activity. Curative activities should be focused mainly on the problems related to management of hospital costs in such areas as:

- costs of excessive stock and medicine consumption,

- overmanning (especially administration),

- covering costs over limits,

- rational management of fixed assets,

- proper allocation of the costs incurred for providing services (the use of advanced systems of cost accounting and cost management).

Managers in hospitals need information about financial and property standing over the broad range and from all areas of activity. However, the most important area of management in hospitals are costs.

\section{Discussion}

The use of the category of costs in the analysis of hospital activities is important, although, undoubtedly, it leads to the necessity of involvement of additional resources. However, it is worth emphasizing that the evaluation of net profit or net loss is not sufficient. Hospital margins indicators may be misleading and they may not sufficiently present the financial position of a hospital [Duffy, Friedman 
1993; Kane 1991; Bazzoli, Andes 1995]. Profit or loss is not necessarily the effect of current activity and it can also result from sporadic, random activities or accounting activities with solely accrual character or the expression of e.g. changes in the rules of evaluation. An important cause of changes in values of hospital costs are the factors which result from changes in health care system (e.g. increased salaries, changes in the system for settlements of services or funds).

The analysis of hospital reports in the area of costs confirms that costs in healthcare have specific features. The necessity of securing patient health needs which are difficult to plan, providing infrastructural background and readiness to provide services mean that the limited financial resources of the health sector should be rational and controlled by financial resources managers. Analyzing the scope of the statutory reporting of financial data for economic and financial situation of hospitals it can be concluded that they lack detailed information on costs. It would be interesting and important to report information on the costs of the resources involved (human, material, including mainly medicines, medical materials and medical fixed assets) as well as the costs of providing readiness to provide benefits. There is also no information in the reports about the costs of benefits over the limit. With the exception of life-saving services, they are not financed by the payer - the National Health Fund.

From the standpoint of founding bodies, information about costs and liabilities is critical since during hospital liquidation processes they will have to be covered from public resources. In addition to obligatory reports about economic and financial standing of SPZOZ, the founding body should be interested in other information (e.g. about costs) which can be additionally presented by the entities. In order for information about costs to be useful for recipients of statements and reports, it should be correctly defined and identified in terms of its scope, structure and hospital specific character. Only in this case it can constitute a reliable basis for the evaluation of the economic and financial standing of the entity while the economic decisions based on this information can be right.

Medical entities, even those carried out in a private form, are not completely autonomous entities of the health care market. Because there is a partial adjustment of wages and prices of medicines and other medical materials, quality requirements and conditions for the realization of health benefits are made. It determines the potential need for supervision and support for medical entities, but must be supported by detailed analytical information, mainly on costs.

The indicated principles and examples represent the arguments for finding the research hypothesis as verified. 


\section{References}

Act of April 15, 2011 on medical activity, Journal of Laws 2018, item 160.

Bazzoli G., Andes S., 1995, Consequences of hospital financial distress, Hospital \& Health Services Administration, 40(4), pp. 472-495.

Bednarski L., 2007, Analiza finansowa w przedsiębiorstwie. PWE, Warszawa, p. 96.

Chluska J., 2011, Problemy analizy kosztów w zarządzaniu SPZOZ, Zeszyty Naukowe Uniwersytetu Szczecińskiego, no. 679, Finanse, Rynki Finansowe, Ubezpieczenia, no. 44, pp. 7-19.

Chluska J., 2017, Wynik finansowy szpitala - aspekty informacyjne i decyzyjne, Prace Naukowe Uniwersytetu Ekonomicznego we Wrocławiu, no. 471, pp. 94-101.

Cygańska M., 2015, Wykorzystanie analizy finansowej do oceny rentowności szpitali - wybrane problemy, Prace Naukowe Uniwersytetu Ekonomicznego we Wrocławiu no. 388, Wrocław, pp. 363-372.

Duffy S.Q., Friedman B, 1993, Hospitals with chronic financial losses: What came next?, Health Affairs, 12,(2), pp. 151-163.

Giancotti M., Guglielmo A., Mauro M., 2017, Efficiency and opitmal size of hospitals: Results of a systematic search, PLoS One, 12(3).

Hosp1: http://www.bip.radom.pl/ra/rada-miejska/uchwaly/39399,Uchwala-nr-5352017-w-sprawieprzyjecia-raportu-o-sytuacji-ekonomiczno-finansowej.html (access: 4.06.2018).

Hosp2: bip.jaworzno.pl/pobierz/61169.html (access: 4.06.2018).

Hosp3: http://bip.powiatsulecinski.pl/system/obj/6278_RP_38_179_17.pdf (access: 4.06.2018).

http://www.rmf24.pl/fakty/news-nowa-wycena-swiadczen-to-katastrofa-ministerstwo-zdrowiaodp,nId,2199230 (access: 10.05.2018).

https://www.polskieradio.pl/42/273/Artykul/1592954,Zmiany-wycen-procedur-medycznych-publiczne-szpitale-sie-ciesza-prywatne-.pl (access: 10.05.2018).

Kane N.M., 1991, Hospital profits, a misleading measure of financial health, The Journal of American Health Policy, no. 1(1), pp. 27-35.

Kludacz M., 2010, Model karty dokonań na potrzeby zintegrowanego systemu oceny działalności szpitali publicznych, [in:] M. Hass-Symotiuk (ed.), Koncepcja sprawozdawczości szpitali na potrzeby zintegrowanego systemu oceny dokonań, Wydawnictwo Naukowe Uniwersytetu Szczecińskiego, Szczecin.

Kotapski R., 2016, Koszty leczenia pacjenta a rachunek kosztów szpitala, Finanse, Rynki Finansowe, Ubezpieczenia, vol 1(79), pp. 487-495, www.wneiz.pl/frfu (access: 24.05.2018).

Kujawska J., 2014, Koszty niewykorzystanych zasobów na oddziale szpitalnym, Prace Naukowe Uniwersytety Ekonomicznego we Wrocławiu, vol. 343, pp. 295-303.

Macario A., Vitez T., Dunn B., McDonald T., 1995, Where are the costs in Perioperative Care?: Analysis of hospital costs and charges for inaptient surgical care, Anesthesiology, vol. 83, pp. 1138-1144.

Magellan, 2014, Raport: Sytuacja finansowa szpitali w Polsce, http://www.magellansa.pl/Portals/1/ Files/Raporty\%20rynkowe/Raport_Sytuacja\%20finansowa\%20szpitali\%20w\%20Polsce.pdf (access: 10.05.2018).

Puls Medycyny, 2016, Ranking największych szpitali w Polsce w 2014 roku, https://static.pb.pl/atta/2879-dodatek.pdf (access: 10.05.2018).

Puls Medycyny, 2017, Ranking największych szpitali w Polsce w 2015 roku, https://pulsmedycyny.pl/ lista-najwiekszych-szpitali-876279 (access: 10.05.2018).

Raulinajtys-Grzybek M., 2016, Znaczenie standardu rachunku kosztów w realizacji polityki zdrowotnej - porównanie międzynarodowe, Studia Ekonomiczne, Zeszyty Naukowe Uniwersytetu Ekonomicznego w Katowicach, vol. 272, pp. 120-130.

Rozporządzenie Ministra Zdrowia i Opieki Społecznej z dnia 22 grudnia 1998 r. w sprawie szczegółowych zasad rachunku kosztów w publicznych zakładach opieki zdrowotnej, Dziennik Ustaw nr 164, poz. 1194 . 
Rozporządzenie Ministra Zdrowia z dnia 8 lipca 2015 r. w sprawie zaleceń dotyczących standardu rachunku kosztów u świadczeniodawców, Dziennik Ustaw 2015, poz. 1126.

Rozporządzenie Ministra Zdrowia z dnia 12 kwietnia 2017 r. w sprawie wskaźników ekonomiczno-finansowych niezbędnych do sporządzenia analizy oraz prognozy sytuacji ekonomiczno-finansowej samodzielnych publicznych zakładów opieki zdrowotnej, Dziennik Ustaw 2017, poz. 832.

Rój J., 2006, Decyzje inwestycyjne i decyzje finansowe w działalności szpitala, [in:] J. Rój, J. Sobiech, (eds.), Zarzadzanie finansami szpitala, Wolters Kluwer, Warszawa.

Szewieczek A., 2017, Selected problems of cost allocation in hospital - relationship between business model and cost structure, 17th International Scientific Conference Globalizaion and Its Socio-Economic Consequences, University of Zilina, 4-5 October 2017, Rajecke Teplice, Slovak Republic, http://ke.uniza.sk\%2Fsites\%2Fdefault\%2Ffiles\%2Fcontent_files\%2Fpart_vi_final_0.pdf, pp. 2610-2617.

Walshe K., Smith J., 2011, Zarzadzanie w opiece zdrowotnej, Wolters Kluwers, Warszawa, p. 27.

Zalewska B., 2017, Rola wskaźników finansowych w analizie i prognozie sytuacji ekonomiczno-finansowej samodzielnych publicznych zakładów opieki zdrowotnej, Zeszyty Naukowe Wydziału Nauk Ekonomicznych, Politechnika Koszalińska, no. 21(1), pp. 373-386. 